\title{
Estrous Cycle Independent Embryo Growth Promoting Activity of Mouse Uterus
}

\author{
Yasuo GOTO, Yoichi NODA, Katsuhiko NARIMOTO, \\ Yoh UMAOKA and Takahide MORI
}

Department of Gynecology and Obstetrics, Kyoto University Faculty of Medicine, 54 Kawahara-cho Shogoin, Sakyo-ku, Kyoto, 606, Japan

\begin{abstract}
To evaluate the intrauterine environment on embryo development, we examined the effects of co-culture with uterine epithelial cells and of uterine fluids on mouse embryo development in vitro. In the co-cultures of mouse uterine epithelial cells and 8-cell embryos, the rate of expanded blastocyst after $24 \mathrm{~h}$ of co-culture and the rates of hatching blastocysts $48 \mathrm{~h}$ and $72 \mathrm{~h}$ after the initiation of co-culture $(29.4 \%, 56.7 \%$ and $78.9 \%$, respectively) were significantly higher than those in the control $\left(11.3 \%, 26.5 \%\right.$ and $49.7 \%$, respectively). The incorporation of $L-\left[4,5-{ }^{3} \mathrm{H}\right]$ leucine by the morulae after 24 $h$ of co-culture was significantly higher than that of the control (an increase of 50.1\%). The similar results were obtained in the cultures of 8-cell embryos in the medium added with uterine fluids. Moreover, the stimulating effect was exerted not only by uterine fluids from random stages of the estrous cycle but also by the fluids collected in three different stages, suggesting that the effect observed in this study might be independent of the estrous cycle. These results suggest that the intrauterine environment promotes the embryo development throughout the estrous cycle.

Key words: Mouse embryo, Co-culture, Uterine fluid, Estrous cycle independency.
\end{abstract}

(J. Reprod. Dev. 38: 211-217, 1992)

$\mathbf{H}$ uman in vitro fertilization and embryo transfer (IVF-ET) has been in clinical use for more than 10 years. The rate of pregnancy, however, is generally low. It is necessary for improving the rate of pregnancy to increase our understanding the embryo and the uterus. As far as the timing and the method of ET are concerned, the present methods may not be based on such an understanding. At present, a majority of clinics perform intrauterine ET using the embryos in relatively early stage such as 2-cell or 4-cell, to make the in vitro culture period as short as possible. Some studies have also shown that pregnancy was achieved by intrauterine transfer of pronuclear stage embryos [1]. These studies suggest that even embryos in such an early stage can grow in the uterus, but the biological basis of ET at such a

Accepted for Publication: June 29, 1992

Correspondence: Y. Noda stage is still obscure.

In this study, to evaluate the intrauterine environment on embryo development, we examined the effects of co-culture with uterine epithelial cells and of uterine fluids on mouse embryo development in vitro.

\section{Materials and Methods}

Mouse embryo recovery and culture conditions

Five units each of pregnant mare serum gonadotropin (PMSG; Teikoku Zoki Co., Tokyo, Japan) and human chorionic gonadotropin (hCG, Teikoku Zoki Co.) were intraperitoneally administrated to 4 -week-old female ICR mice at 48-h intervals to induce superovulation, and then the animals were housed with male mice of the same 
strain overnight. Vaginal plug formation was confirmed in the next morning (Day 1 of pregnancy) and the mice with vaginal plugs were used for the experiments. Embryos were recovered from oviducts or uteri with phosphate buffered saline (PBS). The standard culture medium was BiggersWhitten-Whittingham's (BWW) medium [2] and the standard culture condition was $5 \% \mathrm{CO}_{2}$ in air at $37 \mathrm{C}$.

\section{Culture of mouse uterine epithelial cells}

According to the method of Tomooka et al. [3], the uteri of 3-to 4-week-old female ICR mice were excised and cut longitudinally to expose the endometrial surface. The uterine pieces were transferred to a disposable sterile 50-ml polypropylene tube and rinsed with the culture medium. The uterine pieces were incubated in 10 $\mathrm{ml}$ of a solution of $0.5 \%$ bovine pancreatic trypsin (Sigma Co., St. Louis, U.S.A.) in Ca- and Mg- free PBS. Tissues were first incubated at $4 \mathrm{C}$ for $60 \mathrm{~min}$ and then at $37 \mathrm{C}$ for another $40 \mathrm{~min}$. After incubation, the tube was gently shaken, dissociating the epithelium from the uterine pieces. Sheetlike epithelial fragments in the supernatant were collected with a pipet. The epithelial fragments were subjected to Percoll gradient centrifugation for selection of epithelial tissues [4]. The culture medium was a 1: 1 mixture of Ham's F-12 and DMEM (Sigma Co., St. Louis, U.S.A.), which contained $10 \%$ fetal calf serum (Gibco, New York, U.S.A.). The concentration of $\mathrm{Ca}^{2+}$ in the medium was adjusted to $0.1 \mathrm{mM}$. A suspension of $4-5 \times 10^{5}$ cells per $\mathrm{ml}$ was prepared, and $1 \mathrm{ml}$ of the suspension were sprayed on collagen-coated 24well multiplates (Corning, New York, U.S.A.). The culture condition was $5 \% \mathrm{CO}_{2}$ in air at $37 \mathrm{C}$.

The cells became almost confluent after 3 to 5 days of culture. Observation with a phase-contrast microscope revealed that most of the cells showed an epitheloid pattern.

\section{Incorporation of $\mathrm{L}-\left[4,5-{ }^{3} \mathrm{H}\right]$ leucine by mouse embryos}

The incorporation of L- $\left[4,5-{ }^{3} \mathrm{H}\right]$ leucine (specific activity, 5.0 TBq/m mol; Amersham Japan, Tokyo, Japan) was determined as an index of the amount of protein synthesized by mouse embryos. After embryos were cultured with BWW solution containing $1.85 \mathrm{MBq}$ of $\mathrm{L}-\left[4,5-{ }^{3} \mathrm{H}\right]$ leucine per $\mathrm{ml}$ for $2 \mathrm{~h}$ at $37 \mathrm{C}$, they were washed 3 times with
BWW solution containing a 1,000-fold amount of cold L-leucine (Nacalai Tesque Inc., Kyoto, Japan). Groups of 5 embryos were fused with $1 \mathrm{~N}$ $\mathrm{NaOH}$, which were then neutralized with $0.5 \%$ HCl. Ice-cooled 20\% trichloroacetic acid (TCA; Nacalai Tesque Inc., Kyoto, Japan) was added to each group, and the radioactivity of the TCA insoluble fraction was determined with a liquid scintillation counter.

\section{Collection of mouse uterine fluids}

Eight to 10-week-old female ICR mice were used as fluid donors. According to the method of O'Neill and Quinn [5], the uteri were flushed with $50 \mu \mathrm{l}$ of cold PBS from oviductal ends by using a 32-G injection needle, taking care not to introduce any contaminating fluid or cellular debris into the flushings, which were kept on ice during the collection period. Fluid from 30-40 animals was pooled and centrifugated at $70,000 \mathrm{~g}$ for $60 \mathrm{~min}$ at 4C. The supernatant fluid was dialysed against pure water for $48 \mathrm{~h}$ (using the Visking dialysis tubing, size 36/32). Protein was quantitatively determined by the method of Lowry et al. [6], and the specimen was transferred into several glass tubes. The samples were then freeze-dried and stored at $-76 \mathrm{C}$ until use.

Experiment 1: Co-culture of uterine epithelial cells and embryos

When the cultured uterine epithelial cells became confluent, the culture was washed with BWW solution 3 times, and the pronuclear stage embryos or 8-cell embryos, which were recovered 17 or $66 \mathrm{~h}$ after administration of hCG, were co-cultured in $1 \mathrm{ml}$ of BWW solution containing $0.3 \%$ bovine serum albumin (BSA; Sigma Co., St. Louis, U.S.A.). The embryos were observed every $24 \mathrm{~h}$ with a phase-contrast microscope. The embryos cultured in BWW solution containing $0.3 \%$ BSA without epithelial cells served as the control.

After co-culture of the morulae recovered $72 \mathrm{~h}$ after administration of hCG with uterine epithelial cells for $24 \mathrm{~h}$, the incorporation of $\mathrm{L}-\left[4,5-{ }^{3} \mathrm{H}\right]$ leucine by the embryos was determined by the method described above. The control of the experiment were the embryos which were cultured in BWW solution containing $0.3 \%$ BSA without epithelial cells for $24 \mathrm{~h}$ and used for the incorporation experiment. Moreover, the embryos which 
were recovered $96 \mathrm{~h}$ after administration of hCG were immediately used for the incorporation experiment (in vivo group).

Experiment 2: Addition of uterine fluids from mice at random stages of the estrous cycle

Uterine fluids were collected from mice at random stages of the estrous cycle by the method described above. The amount of protein in the uterine fluids was adjusted to $1 \mathrm{mg} / \mathrm{ml}$ by adding BWW solution containing $0.3 \%$ BSA to glass tubes, and $100 \mu \mathrm{l}$ quantities were dropped into wells of a 4-well multidish (Nunc, Roskilde, Denmark). The pronuclear stage embryos or 8-cell embryos, which were recovered 17 or $66 \mathrm{~h}$ after administration of hCG, were cultured in the drops under mineral oil. The embryos were observed every $24 \mathrm{~h}$ with a phase-contrast microscope. The embryos cultured in $\mathrm{BWW}$ solution containing $0.4 \% \mathrm{BSA}$ served as the control.

After the morulae recovered $72 \mathrm{~h}$ after administration of hCG were cultured in uterine-fluidsadded BWW solution for $24 \mathrm{~h}$, the incorporation of $\mathrm{L}-\left[4,5-{ }^{3} \mathrm{H}\right]$ leucine by the embryos was determined. The control of the experiment were the embryos which were cultured in BWW solution containing $0.4 \% \mathrm{BSA}$ for $24 \mathrm{~h}$ and used for the incorporation experiment. Moreover, the embryos which were recovered $96 \mathrm{~h}$ after administration of hCG were immediately used for the incorporation experiment (in vivo group).

\section{Experiment 3: Addition of uterine fluids from mice at different stages}

Uterine fluids samples were taken at 3 different stages; (1) $20 \mathrm{~h}$ after administration of PMSG (5 units), (2) $20 \mathrm{~h}$ after administration of hCG (5 units) following PMSG (5 units) administration at 48-h earlier, and (3) on Day 4 of pregnancy following natural mating. After the morulae recovered $72 \mathrm{~h}$ after administration of hCG were cultured in BWW solution with one of these uterine fluid specimens for $24 \mathrm{~h}$, the incorporation of $\mathrm{L}-\left[4,5-{ }^{3} \mathrm{H}\right]$ leucine by the embryos was determined. The embryos which were cultured in BWW solution containing $0.4 \%$ BSA for $24 \mathrm{~h}$ served as the control.

\section{Results}

Experiment 1: Co-culture of uterine epithelial cells and embryos

In the co-cultures of mouse uterine epithelial cells and 8-cell embryos, the rate of expanded blastocyst after $24 \mathrm{~h}$ of co-culture (Day 4) was $29.4 \%$, which was significantly $(\mathrm{P}<0.01)$ higher than the $11.3 \%$ in the control, although there was no significant difference in the rate of blastocysts between the co-culture group and the control group on Day 4. The rates of hatching blastocysts $48 \mathrm{~h}$ (Day 5) and $72 \mathrm{~h}$ (Day 6 ) after the initiation of co-culture were $56.7 \%$ and $78.9 \%$, respectively, which were significantly $(\mathrm{P}<0.01)$ higher than the $26.5 \%$ and $49.7 \%$, respectively, in the control (Table 1). No effect of co-culture was observed on the development of pronuclear stage embryos (Table 2).

The incorporation of $\mathrm{L}-\left[4,5-{ }^{3} \mathrm{H}\right]$ leucine by the embryos after co-culture for $24 \mathrm{~h}$ was significantly $(\mathrm{P}<0.01)$ higher than that of the control (an

Table 1. In vitro development of 8-cell mouse embryos in co-culture with uterine epithelial cells

\begin{tabular}{|c|c|c|c|c|c|c|}
\hline & \multirow{2}{*}{$\begin{array}{c}\text { No. of } \\
\text { experiments }\end{array}$} & \multirow{2}{*}{$\begin{array}{l}\text { No. of } \\
\text { embryos }\end{array}$} & \multicolumn{4}{|c|}{ No. $(\%)$ of embryos developed to } \\
\hline & & & $\begin{array}{l}\text { Blastocyst } \\
\text { (Day 4 }{ }^{\text {a }}\end{array}$ & $\begin{array}{l}\text { Expanded } \\
\text { Blastocyst } \\
\text { (Day 4) }\end{array}$ & $\begin{array}{l}\text { Hatching } \\
\text { Blastocyst } \\
\left(\text { Day } 5^{\mathrm{b}}\right)\end{array}$ & $\begin{array}{l}\text { Hatching } \\
\text { Blastocyst } \\
\left(\text { Day } 6^{c}\right)\end{array}$ \\
\hline Co-culture & 6 & 194 & $105(54.1 \%)$ & $57 *(29.4 \%)$ & $110 *(56.7 \%)$ & $153 *(78.9 \%)$ \\
\hline Control $^{\mathrm{d}}$ & 6 & 151 & $79(52.3 \%)$ & $17(11.3 \%)$ & $40(26.5 \%)$ & $75(49.7 \%)$ \\
\hline
\end{tabular}

Twenty five to 33 embryos were used per experiment.

a Twenty four h after the initiation of co-culture.

b Forty eight $\mathrm{h}$ after the initiation of co-culture.

c Seventy two h after the initiation of co-culture.

d Culture in BWW medium supplemented with $0.3 \%$ BSA.

* $\mathrm{P}<0.01$, significantly different from the control $\left(\chi^{2}\right.$ test $)$. 
Table 2. In vitro development of pronuclear stage mouse embryos in coculture with uterine epithelial cells

\begin{tabular}{|c|c|c|c|c|}
\hline & \multirow{2}{*}{$\begin{array}{c}\text { No. of } \\
\text { experiments }\end{array}$} & \multirow{2}{*}{$\begin{array}{l}\text { No. of } \\
\text { embryos }\end{array}$} & \multicolumn{2}{|c|}{ No. $(\%)$ of embryos developed to } \\
\hline & & & 4-cell & Blastocyst \\
\hline Co-culture & 6 & 127 & $29^{\mathrm{NS}}(22.8 \%)$ & $5^{\mathrm{NS}}(3.9 \%)$ \\
\hline Control $^{\mathrm{a}}$ & 6 & 145 & $32 \quad(22.1 \%)$ & $4 \quad(2.8 \%)$ \\
\hline
\end{tabular}

Twenty to 25 embryos were used per experiment. ${ }^{\text {a}}$ Culture in BWW

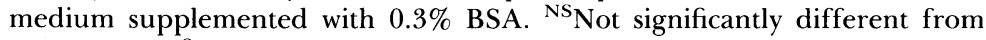
the control $\left(\chi^{2}\right.$ test $)$.

Table 3. Incorporation of $\mathrm{L}-\left[4,5-{ }^{3} \mathrm{H}\right]$ leucine by mouse embryos

\begin{tabular}{|c|c|c|}
\hline \multicolumn{2}{|c|}{ Experimental groups } & \multirow{2}{*}{$\begin{array}{l}\begin{array}{l}\text { Incorporation } \\
\text { (cpm/2 h/embryo) }^{\mathrm{a}}\end{array} \\
2909.6 \pm 123.3^{*} \\
1938.3 \pm 138.5 \\
3696.1 \pm 129.2 \#\end{array}$} \\
\hline Experiment 1 & $\begin{array}{l}\text { co-culture } \\
\text { control } \\
\text { in vivo }\end{array}$ & \\
\hline Experiment 2 & $\begin{array}{l}\text { uterine fluids }{ }^{b} \\
\text { control } \\
\text { in vivo }\end{array}$ & $\begin{array}{l}2821.1 \pm 140.6^{*} \\
2152.6 \pm 89.4 \\
3763.3 \pm 134.6 \#\end{array}$ \\
\hline Experiment 3 & $\begin{array}{l}\text { uterine fluids; P } \\
\text { uterine fluids; P-H } \\
\text { uterine fluids; Day } 4 \\
\text { control }\end{array}$ & $\begin{array}{l}2865.6 \pm 138.6^{*} \\
2800.3 \pm 170.1^{*} \\
2980.0 \pm 188.1^{*} \\
2083.8 \pm 116.1\end{array}$ \\
\hline
\end{tabular}

\footnotetext{
${ }^{a}$ Values are mean \pm s.e.m. for 9 replicates per experiment. ${ }^{b}$ Collected from mice at random stages of the estrous cycle. P; $20 \mathrm{~h}$ after PMSG administration. $\mathrm{P}-\mathrm{H} ; 20 \mathrm{~h}$ after administration of hCG following PMSG administration at 48-h earlier. Day 4; on Day 4 of pregnancy following natural mating. $* \mathrm{P}<0.01$, significantly different from the control (student's $t$-test). \# $\mathrm{P}<0.01$, significantly different from other groups (student's $t$-test).
}

increase of $50.1 \%$ ), showing an increase in the amount of protein synthesized.

However, the level was still lower than that in in vivo group $(\mathrm{P}<0.01)$ (Table 3$)$.

\section{Experiment 2: Addition of uterine fluids from} mice at random stages of the estrous cycle

In the cultures of 8-cell embryos in uterinefluids-added medium, the rate of expanded blastocysts on Day 4 was $43.7 \%$, which was significantly $(\mathrm{P}<0.05)$ higher than the $27.8 \%$ in the control, although there was no significant difference in the rate of blastocysts between the 2 groups on Day 4 . The rates of hatching blastocysts on Day 5 and on Day 6 were $44.8 \%$ and $70.1 \%$, respectively, which were significantly $(\mathrm{P}<0.01)$ higher than the $19.6 \%$ and $53.6 \%$, respectively, in the control (Table 4). No effect of the addition of the uterine fluids was observed on the development of pronuclear stage embryos (Table 5).

The incorporation of $\mathrm{L}-\left[4,5-{ }^{3} \mathrm{H}\right]$ leucine by the embryos after culture in uterine-fluids-added medium for $24 \mathrm{~h}$ was significantly $(\mathrm{P}<0.01)$ higher than that of the control (an increase of $31.0 \%$ ), showing an increase in the amount of protein synthesized. However, the level was still lower than that in in vivo group $(\mathrm{P}<0.01)$ (Table 3$)$.

\section{Experiment 3: Addition of uterine fluids from mice at different stages}

All of the cultures to which uterine fluids from different stages were added showed significantly $(\mathrm{P}<0.01)$ higher incorporation of $\mathrm{L}-\left[4,5-{ }^{3} \mathrm{H}\right]$ leucine than the control group, but there was no difference among the 3 groups (Table 3). No suppressive effect was observed in any culture to 
Table 4. Effects of uterine fluids on in vitro development of 8-cell mouse embryos

\begin{tabular}{|c|c|c|c|c|c|c|}
\hline & \multirow{2}{*}{$\begin{array}{c}\text { No. of } \\
\text { experiments }\end{array}$} & \multirow{2}{*}{$\begin{array}{l}\text { No. of } \\
\text { embryos }\end{array}$} & \multicolumn{4}{|c|}{ No. $(\%)$ of embryos developed to } \\
\hline & & & $\begin{array}{l}\text { Blastocyst } \\
\text { (Day } 4^{\mathrm{a}} \text { ) }\end{array}$ & $\begin{array}{c}\text { Expanded } \\
\text { Blastocyst } \\
\text { (Day 4) }\end{array}$ & $\begin{array}{c}\text { Hatching } \\
\text { Blastocyst } \\
\left(\text { Day } 5^{\text {b) }}\right.\end{array}$ & $\begin{array}{c}\text { Hatching } \\
\text { Blastocyst } \\
\left.\text { (Day } 6^{c}\right)\end{array}$ \\
\hline $\begin{array}{l}\text { Uterine fluids }{ }^{\mathrm{d}} \\
\text { added }\end{array}$ & 4 & 87 & $72(82.8 \%)$ & $38 *(43.7 \%)$ & $39 * *(44.8 \%)$ & $61^{* *}(70.1 \%)$ \\
\hline Control $^{e}$ & 4 & 97 & $79(81.4 \%)$ & $27(27.8 \%)$ & $19 \quad(19.6 \%)$ & $52 \quad(53.6 \%)$ \\
\hline
\end{tabular}

Twenty to 25 embryos were used per experiment. "Twenty four $\mathrm{h}$ after the initiation of culture. 'Forty eight $\mathrm{h}$ after the initiation of culture. "Seventy two $\mathrm{h}$ after the initiation of culture. " Uterine fluids collected from mice at random stages of the estrous cycle. ${ }^{e}$ Culture in BWW medium supplemented with $0.4 \%$ BSA. $* \mathrm{P}<0.05$, significantly different from the control $\left(\chi^{2}\right.$ test $) .{ }^{*} * \mathrm{P}<0.01$, significantly different from the control ( $\chi^{2}$ test).

Table 5. Effects of uterine fluids on in vitro development of pronuclear stage mouse embryos

\begin{tabular}{|c|c|c|c|c|}
\hline & \multirow{2}{*}{$\begin{array}{c}\text { No. of } \\
\text { experiments }\end{array}$} & \multirow{2}{*}{$\begin{array}{c}\text { No. of } \\
\text { embryos }\end{array}$} & \multicolumn{2}{|c|}{ No. (\%) of embryos developed to } \\
\hline & & & 4-cell & Blastocyst \\
\hline $\begin{array}{l}\text { Uterine fluids } \\
\text { added }\end{array}$ & 4 & 82 & $28^{\mathrm{NS}}(34.1 \%)$ & $6^{\mathrm{NS}}(7.3 \%)$ \\
\hline Control $^{\text {b }}$ & 4 & 78 & $(35.9 \%)$ & $5 \quad(6.4 \%)$ \\
\hline
\end{tabular}

Nineteen to 21 embryos were used per experiment. ' Uterine fluids collected from mice at random stages of the estrous cycle. ' Culture in BWW medium supplemented with $0.4 \%$ BSA. ${ }^{\text {NS }}$ Not significantly different from the control ( $\chi^{2}$ test).

which uterine fluids were added.

\section{Discussion}

Co-culture of embryos and somatic cells is regarded as an in vitro model for determination of factors necessary for growth of embryos and of their interaction. Accordingly, attempts at coculture between embryos in each stage and somatic cells of such organs as the oviduct and the uterus have been made in many species of mammals including the mouse. Some combinations are reported to stimulate the embryo growth [7]. Co-culture of embryos with uterine cells stimulated the growth of bovine morulae in some studies [8] and the growth of 8-cell mouse embryos in others [9]. Our results also showed that coculture of embryos and uterine epithelial cells stimulated the growth of mouse embryos at least after 8-cell stage. The stimulating effect was observed as measured not only by morphological criteria such as the rates of blastocysts and hatching blastocysts but also biochemical indices such as the amino acid incorporation. However, no stimulating effect was observed on pronuclear stage embryos. Rexroad and Powell [10] co-cultured one-cell ovine ova with oviductal cells and found the increased development of embryos. The same result was reached by Gandolfi and Moor [11]. Similarly, Noda et al. [12] reported that co-culture of pronuclear stage mouse embryos with hamster oviductal cells stimulated the embryo growth. Rexroad [7] stated that the type of cell that is optimal in co-culture with embryos may depend on the stage of development of the embryo. In the available literature, it seems that oviductal cells have been effective for 1-cell and 2-cell embryos and that uterine cells have been effective for morulae and blastocysts. Recently, we have reported that the first cell cycle must be protected from oxidative stress to overcome the blocking phenomenon that occurs in the following cell cycle $[13,14,15]$. The release of the antioxidant activity from somatic cells into the culture medium is considered to be highly likely in co-culture system. The difference of the biological functions between oviductal and uterine cells could be discussed from 
this point of view.

Noda et al. [12] reported that the conditioned medium obtained by the culture of somatic cells exerted no such stimulating effect and reached the conclusion that the factor observed in co-culture was not a stable substance easily transferred from one culturing system to another such as a glycoprotein but was a substance of a very short life time that could exist only in a medium containing living cells. Anyway, there have been no reports on isolation of the embryo growth stimulating factor in any co-culture experiment.

Uterine fluids are believed to express the intrauterine environment directly surrounding embryos, they have been analyzed for a long time. The attempts at analysis are divided into chemical analysis and analysis using the embryo culture system. As for the first type of analysis, numerous reports have appeared over the last several years that deal with uterine secreted substances including steroids, prostaglandins, histamine and proteins $[16,17,18]$. Particularly, uterine secreted proteins are believed to be involved in the implantation and the interactions between the embryo and the uterus $[19,20]$. However, there has not been good agreement about which proteins actually change in various species or what functions they subserve. As for the second type, some studies have shown that uterine fluids stimulate embryo growth under specific conditions [21, 22, 23, 24]. However, uterine fluids have also been reported to inhibit the incorporation of $\left[{ }^{3} \mathrm{H}\right]$ uridine by mouse blastocysts [5, 25]. Hence, no definite opinion has been established on uterine fluids. Toole et al. [24] stated that substances in uterine secretions could have inhibitory and stimulatory influences on the early development of embryos. In our present experiments, however, the macromolecular components of uterine fluids exerted a certain stimulating effect on the in vitro growth of embryos at least after 8-cell stage, and the effect was observed morphologically and biochemically, showing a pattern similar to that observed in the co-culture experiments. Weitlauf [25] has shown that the inhibitory effect can be removed by dialysis. As far as the smaller molecular components, other analyses should be needed.

The most important point of this study is that the stimulating effect was exerted not only by uterine fluids in the specific stage but also by the fluids collected in 3 different stages. These results suggest that the embryo stimulating effect of uterine fluids observed in this study may be independent of the estrous cycle. Although the nature of the stimulating effect remains unclear, it seems unlikely that uterus specific growth stimulating factors are involved, judging from the finding that a similar effect was observed throughout the estrous cycle. Several growth factor receptors such as insulin-like growth factor (IGF)-Ireceptor and insulin-receptor are detected in mouse embryos from the 8-cell stage, although insulin or IGF-I mRNA are not found in preimplantation mouse embryos [26]. These growth factors might be involved in the stimulating activity of uterine fluids.

Thus, the intrauterine environment is considered to promote the embryo development throughout the estrous cycle. This estrous cycle independency may be the experimental confirmation of the fact that ET even in the nonphysiological stage is providing pregnancies in human IVF-ET, although the rate is low. In mouse intrauterine ET, however, the combination of donor and recipient is believed to be the determinant of the rate of implantation. Some studies [27, 28] have shown that ET by an inappropriate combination yields only a limited rate of implantation while that by the appropriate combination yields a high rate. This estrous cycle dependency cannot be explained only by our present attempt at in vitro analysis of the intrauterine environment. To solve this contradiction, the fate of embryos transferred into the uterus by an inappropriate combination remains to be elucidated. The intrauterine environment should also be analyzed in vivo as well.

\section{Acknowledgments}

The authors express their great thanks to Dr. Y. Tomooka (Tsukuba Life Science Center) for his kind instructions in culture of mouse uterine epithelial cells. This study was supported by Grants in Aid for General Scientific Research B by the Ministry of Education, Science and Culture (No. 03454395) and for the Scientific Research on Priority Area (No. 03207104). 


\section{References}

1. Ahuja KK, Smith W, Tucker M, Craft I. Successful pregnancies from the transfer of pronucleate embryos in an outpatient in vitro fertilization program. Fertil Steril 1985; 44: 181-184.

2. Biggers JD, Whitten WK, Whittingham DG. The culture of mouse embryos in vitro. In: Daniel JC Jr(ed.), Methods in Mammalian Embryology. San Francisco: Freeman Co.; 1971: 86-116.

3. Tomooka Y, DiAugustine RP, McLachlan JA. Proliferation of mouse uterine epithelial cells in vitro. Endocrinology 1986; 118: 1011-1018.

4. Imagawa M, Tomooka Y, Yang J, Guzman R, Richards J, Nandi S. Isolation and serum-free cultivation of mammary epithelial cells within a collagen gel matrix. In: Barnes DW, Sirbasku DA, Sato GH(eds.), Methods for Serum-free Culture of Cells of the Endocrine System, New York: Alan R. Liss; 1984: 127-141.

5. O'Neill C, Quinn P. Interactions of uterine flushings with mouse blastocysts in vitro as assessed by the incorporation of $\left[{ }^{3} \mathrm{H}\right]$-uridine. J Reprod Fert 1981; 62: 257-262.

6. Lowry OH, Rosebrough NJ, Farr AL, Randall RJ. Protein measurement with the folinphenol reagent. J Biol Chem 1951; 193: 265-275.

7. Rexroad CEJr. Co-culture of domestic animal embryos. Theriogenology 1989; 31: 105-114.

8. Kuzan FB, Wright RWJr. Observations on the development of bovine morulae on various cullular and noncellular substrata. J Anim Sci 1982; 54: 811-816.

9. Lavranos TC, Seamark RF. Addition of steroids to embryo-uterine monolayer co-culture enhances embryo survival and implantation in vitro. Reprod Fertil Dev 1989; 1: 41-46.

10. Rexroad CEJr, Powell AM. Coculture of ovine ova with oviductal cells in medium 199. J Anim Sci 1988; 66: 947-953.

11. Gandolfi F, Moor RM. Stimulation of early embryonic development in the sheep by co-culture with oviduct epithelial cells. J Reprod Fert 1987; 81 : 23-28.

12. Noda Y, Narimoto K, Umaoka Y, Natsuyama S, Mori T. Analysis of oviduct-derived embryonic growth stimulator activity. Int J Fertil 1992; "in press".

13. Noda Y, Matsumoto $\mathbf{H}$, Umaoka Y, Tatsumi K, Kishi J, Mori T. Involvement of superoxide radicals in the mouse 2-cell block. Molec Reprod Develop 1991; 28: 356-360.

14. Umaoka Y, Noda Y, Narimoto K, Mori T. Effects of oxygen toxicity on early development of mouse embryos. Molec Reprod Develop 1992; 31: 28-33.

15. Goto Y, Noda Y, Narimoto K, Umaoka Y, Mori T. Oxidative stress on mouse embryo development in vitro. Free Radical Biol Med 1992; 13: 47-53.

16. Heap RB, Flint AP, Gadsby JG. Role of embryonic signals in the establishment of pregnancy. $\mathrm{Br}$ Med Bull 1979; 35: 129-135.

17. Sauer MJ. Hormone involvement in the establishment of pregnancy. $J$ Reprod Fert 1979; 56: 725743.

18. Kennedy TG. Embryonic signals and the initiation of blastocyst implantation. Aust J Biol Sci 1983; 36: 531-543.

19. Aitken RJ. Uterine proteins. Oxford Rev Reprod Biol 1979; 1: 351-382.

20. Nieder GL, Weitlauf HM, Suda-Hartman M. Synthesis and secretion of stage-specific proteins by peri-implantation mouse embryos. Biol Reprod 1987; 36: 687-699.

21. El-Banna AA, Daniel JCJr. Stimulation of rabbit blastocysts in vitro by progesterone and uterine proteins in combination. Fertil Steril 1972; 23: 101-104.

22. Maurer RR, Beier HM. Uterine proteins and development in vitro of rabbit preimplantation embryos. J Reprod Fert 1976; 48: 33-41.

23. Laster DB, Maurer RR, Chenault JR. Uterine flushings on in vitro growth of bovine embryos. $J$ Anim Sci 1978; 47 (Suppl 1): 373.

24. Toole RJ, Gwazdauskas FC, Whittier WD, Vinson WE. Influence of uterine flushings from superovulated cows on in vitro bovine morulae development. Theriogenology 1988; 30: 811-822.

25. Weitlauf HM. Effect of uterine flushings on RNA synthesis by "implanting" and "delayed implanting" mouse blastocysts in vitro. Biol Reprod 1976; 14: 566-571.

26. Rappolee DA, Sturm KS, Schultz GA, Pedersen RA, Werb Z. The expression of growth factor ligands and receptors in preimplantation mouse embryos. In: Heyner S, Wiley LM(eds.), Early Embryo Development and Paracrine Relationships. New York: Alan R. Liss; 1990: 11-25.

27. McLaren A, Michie D. Studies on the transfer of fertilized mouse egg to uterine foster-mothers I. Factors affecting the implantation and survival of native and transferred eggs. $J$ Exp Biol 1956; 33: 394-416.

28. Fisher DL, Smithberg M. Host-transplant relationship of cultured mouse embryos. J Exp Zool 1973; 183: 263-266. 